\title{
Experimental Study on the Effect of Bore Up, Stroke Up, and the Use of Valves on 105 cc Engine Perfomance
}

\author{
Rochmad Novian Inderanata ${ }^{1, *}$, Thomas Sukardi ${ }^{1}$, Slamet Priyanto ${ }^{2}$ \\ ${ }^{1}$ Mechanical Engineering Education, Yogyakarta State University, Yogyakarta, Indonesia \\ ${ }^{2}$ Mechanical Engineering Education, Sarjanawiyata Tamansiswa University, Yogyakarta, Indonesia \\ *Corresponding author: inderanata@gmail.com
}

Received October 17, 2019; Revised November 20, 2019; Accepted November 28, 2019

\begin{abstract}
On a 4-stroke engine, valve work and function have a very big influence on engine performance and characteristics. To improve engine performance, one of them is by way of bore up. This study aims to determine and compare the performance of a standard 4 stroke 105 cc engine before and after bore ups, stroke ups and the use of racing valves in testing power $(\mathrm{P})$, torque $(\mathrm{T})$ and fuel consumption $\left(m_{f}\right)$. This research method uses a 4 stroke $105 \mathrm{cc}$ standard engine and a $150 \mathrm{cc}$ bore up engine with a variety of standard and racing valves. The testing method uses the throttle method spontaneously from $4000 \mathrm{rpm}$ to $1100 \mathrm{rpm}$ and the throttle method per $1000 \mathrm{rpm}$ from $4000 \mathrm{rpm}$ then is increased to 8000 rpm gradually. Data taken in this study are torque (T), power $(\mathrm{P})$, and fuel consumption $\left(m_{f}\right)$. The results showed that by changing the volume of the cylinder (bore up) by using variations of the racing valve can significantly improve engine performance. The average value of the percentage increase in torque power and fuel consumption compared to the results on a standard 4-stroke engine. On a standard 105 cc engine for 8000 rpm engine speed, $4.63(\mathrm{~N} . \mathrm{m})$ of torque, $3.90(\mathrm{~kW})$ of power obtained and $0.879(\mathrm{~kg} / \mathrm{h})$ of fuel consumption. In a semi racing engine at $8000 \mathrm{rpm}$, torque is $9.45(\mathrm{~N} . \mathrm{m})(104,10 \%)$, power is $8.13(\mathrm{~kW})(108,46 \%)$ and fuel consumption is $1.118(\mathrm{~kg} / \mathrm{h})(27 \%)$. In a full $150 \mathrm{cc}$ racing engine for $8000 \mathrm{rpm}$ engine speed the torque is 12.87 $(\mathrm{N} . m)(177,97 \%)$, the power is $10.79(\mathrm{~kW})(176,67)$ and fuel consumption is $1.116(\mathrm{~kg} / \mathrm{h})(26,96 \%)$.
\end{abstract}

Keywords: bore up, stroke up, intake valve, exhaust valve, throttle

Cite This Article: Rochmad Novian Inderanata, Thomas Sukardi, and Slamet Priyanto, "Experimental Study on the Effect of Bore Up, Stroke Up, and the Use of Valves on 105 cc Engine Perfomance.” American Journal of Mechanical Engineering, vol. 7, no. 4 (2019): 188-194. doi: 10.12691/ajme-7-4-5.

\section{Introduction}

The need for practical transportation equipment that has advantages both machine performance and the technology that is applied is very attractive to people in Indonesia. Currently, motorbikes are the most common means of transportation in Indonesia. Based on statistical data center, the use of motorcycle transportation in Indonesia has increased by $40.81 \%$ from 2014-2017 [1]. Aside from being a means of transportation, motorbikes are also used for competitions, namely racing. The motorcycle used for the competition certainly has a different arrangement than the motorcycle used for daily transportation. In motor racing has been modified on several systems and components to improve the performance of the engine. Regulation of the Minister of Transportation of the Republic of Indonesia Number 33 of 2018 concerning testing of the type of motorized vehicle in Article 1: Paragraph 2 explains that the design and engineering of motorized vehicles is a careful examination of noise in accordance with technical requirements; paragraph 17 explains that the modification of a motorized vehicle is to change the technical specifications of the dimensions, machinery, and / or the carrying capacity of a motorized vehicle [2].

Modifications are made by changing standard components or replacing components and adding components that support to improve the performance of a vehicle engine, especially modifying the combustion chamber by changing the cylinder volume to be bigger (bore up) and raising the piston stroke to be longer (stroke up) [3]. Motor performance which includes power and torque is greatly influenced by the magnitude of the variable length of the crankshaft, the diameter of the piston and the size of the combustion chamber, so that the greater the variables, the greater the value of power and torque [4].

Cylinder boring is a technique used to increase the diameter in cylindrical bore, to produce high power performance from burning fuel under high pressure [5]. This process is used to achieve three different qualities for boring: 1) Concentricity (geometry); 2) Straightness (holes); 3) Sizing (diameter)

From literature, the optimal position angle of the throttle valve opening is used to reduce $\mathrm{CO}$ exhaust gas and noise and vibration, because the throttle body can control the flow of air into the engine cylinder (fuel ratio) and mixing of HC fuel [6] 
The purpose of this study was to determine the performance of the engine produced by the use of racing valves, bore up and stroke up on the cylinder head

\section{Experimental Setup}

Experiment settings that consist of engine specifications, tools, materials, and test equipment schemes for taking torque, power and fuel consumption data contained in tables and figures.

The engine specification data is in Table 1.

\subsection{Research Tool and Material}

In this experimental study, the tools and materials used are as in Table 2, Table 3 and Table 4.

\subsubsection{Material}

The materials used in this study are in the Table 2.

The fuel used in this study is Pertamax. Pertamax is a fuel that has an octane number (RON) of at least 92.0 intended for vehicle engines that have a compression ratio between 9: 1 to 10: 1 , as shown in Table 3.

Table 1. 4-Stroke engine spesifications

\begin{tabular}{|c|c|}
\hline Brand & Yamaha \\
\hline Type & Vega \\
\hline \multicolumn{2}{|l|}{ Machine } \\
\hline Machine type & 4 Stroke Air Cooled \\
\hline Bore x Stroke & $49,50 \times 54 \mathrm{~mm}$ \\
\hline Cylinder Volume & 103,9 сc \\
\hline Cylindrical Arrangement & Horizontal one \\
\hline Transmission gears & 4 speed \\
\hline Operating pattern & N-1-2-3-4 (return) \\
\hline Coupling & Manual, Wet, Multiplate \\
\hline Carburettor & VM 17 x 1 Mikuni with a venturi hole 17 mm \\
\hline Chamshaft standar & Duration $260^{\circ}$ \\
\hline Starter system & Motor Starter dan Crank Starter \\
\hline Valve & Intake 26 mm Exhaust 22 mm \\
\hline \multicolumn{2}{|l|}{ Electricity } \\
\hline Battery & 12V5AH \\
\hline Spark plugs & C6HSA/W20FS-U \\
\hline Ignition system & CDI 5ER-10 \\
\hline \multicolumn{2}{|l|}{ Frame } \\
\hline Frame type & Pipe \\
\hline Front suspension & Telescopic Fork \\
\hline Back suspension & Swing Arm \\
\hline Front tire & 70/90-17M/C38P \\
\hline Back tire & 80/90-17M/C44P \\
\hline Front brake & Hydraulic discs \\
\hline Rear brake & Drum brake \\
\hline \multicolumn{2}{|l|}{ Dimension } \\
\hline Long x Wide x High & 1890 x 675 x $1030 \mathrm{~mm}$ \\
\hline Wheelbase & $1195 \mathrm{~mm}$ \\
\hline Lowest distance to the ground & $146 \mathrm{~mm}$ \\
\hline Tank capacity & 4,2 liters \\
\hline Weight & $95,1 \mathrm{~kg}$ \\
\hline
\end{tabular}

Table 2. research material

\begin{tabular}{|l|l|}
\hline Fuel & Pertamax \\
\hline \multirow{2}{*}{ Brand valve } & Sonic \\
\hline \multirow{2}{*}{ Piston racing } & Inlet $14711-$ KGH-900 diameter $28 \mathrm{~mm}$ \\
\cline { 2 - 2 } & Exhaust $14721-\mathrm{KTY}-\mathrm{H} 50$ diameter $24 \mathrm{~mm}$ \\
\hline Chamshaft racing & $\begin{array}{l}\text { Diameter } 57 \mathrm{~mm} \\
\text { The length of the piston rod is } 57.9 \mathrm{~mm} \text { with a stroke of } 6 \mathrm{~mm}\end{array}$ \\
\hline Carburettor & Duration $280^{\circ}$ \\
\hline Ignition Coil & PE venturi hole diameter of $28 \mathrm{~mm}$ \\
\hline
\end{tabular}


Table 3. characteristic of pertamax (Source: Pertamina Industrial Fuel Marketing, 2019)

\begin{tabular}{|c|c|c|c|c|c|c|}
\hline \multirow{2}{*}{ No. } & \multirow{2}{*}{ CHARACTERISTIC } & \multirow{2}{*}{ UNIT } & \multicolumn{2}{|c|}{ LIMITATION } & \multicolumn{2}{|c|}{ TEST METHOD } \\
\hline & & & MIN & MAX & ASTM & OTHERS \\
\hline 1. & Research Octana Numbers & RON & 92,0 & - & D 2699 & \\
\hline 2. & Oxidation Stability & Minutes & 480 & - & D 525 & \\
\hline 3. & Sulfur content & $\% \mathrm{~m} / \mathrm{m}$ & - & $0,05^{1)}$ & D 2622 / D 4294 & \\
\hline 4. & Lead Content $(\mathrm{Pb})$ & griliter & - & $0,013^{22}$ & D 3237 & \\
\hline 5. & Phosphorus content & $\mathrm{mg} / \mathrm{l}$ & - & - & D 3231 & \\
\hline 6. & Metal content (Mn, Fe, dll) & $\mathrm{mg} / \mathrm{h}$ & - & - & D 3831 & \\
\hline 7. & Silicon Content & $\mathrm{mg} / \mathrm{kg}$ & - & - & \multicolumn{2}{|c|}{$\begin{array}{l}\text { IICP-AES (Refer to the in house method with } \\
\text { detection limits }=1 \mathrm{mg} / \mathrm{kg} \text { ) }\end{array}$} \\
\hline 8. & Oxygen content & $\% \mathrm{~m} / \mathrm{m}$ & - & $2.7^{3 /}$ & D 4815 & \\
\hline 9. & Olefin content & $\%$ viv & - & 4) & D 1319 & \\
\hline 10. & Aromatic Content & $\%$ viv & - & 50,0 & D 1319 & \\
\hline \multirow{7}{*}{$\begin{array}{l}11 . \\
12 .\end{array}$} & Benzene contert & \% viv & - & 5,0 & D 4420 & \\
\hline & Distillation: & & & & D 86 & \\
\hline & $10 \%$ vol. evaporation & ${ }^{\circ} \mathrm{C}$ & - & 70 & & \\
\hline & $50 \%$ vol. evaporation & ${ }^{\circ} \mathrm{C}$ & 77 & 110 & & \\
\hline & $90 \%$ vol. evaporation & ${ }^{\circ} \mathrm{C}$ & 130 & 180 & & \\
\hline & Titk didih akhir & ${ }^{\circ} \mathrm{C}$ & - & 215 & & \\
\hline & Residu & $\%$ Viv & - & 2,0 & & \\
\hline 13. & Sediment & $\mathrm{mg} / \mathrm{l}$ & - & 1 & D 5452 & \\
\hline 14. & Unwashed Gum & $\mathrm{mg} / 100 \mathrm{ml}$ & - & 70 & D 381 & \\
\hline 15. & Washed Gum & $\mathrm{mg} / 100 \mathrm{ml}$ & - & 5 & D 381 & \\
\hline 16. & Steam Pressure & $\mathrm{kPa}$ & 45 & 60 & D 5191 / D 323 & \multirow{5}{*}{$\mathbb{P} 30$} \\
\hline 17. & Specific Gravity (at $15 \propto C)$ & $\mathrm{kg} / \mathrm{m}^{3}$ & 715 & 770 & D 4052 / D 1298 & \\
\hline 18. & Copper Blade Corrosion & merit & \multicolumn{2}{|c|}{ Class 1} & D 130 & \\
\hline 19. & Doctor Test & & & & & \\
\hline 20. & Sulfur Mercaptans & $\%$ massa & - & 0,002 & D 3227 & \\
\hline 21. & Visual appearance & & \multicolumn{2}{|c|}{ Clear and bright } & & \\
\hline 22. & Color & & \multicolumn{2}{|c|}{ Blue } & & \\
\hline 23. & Coloring Cortents & gri/100I & - & 0,13 & & \\
\hline
\end{tabular}

Table 4. research tool

Dyno test:
An instrument for measuring the torque of an engine
$\begin{aligned} & \text { Tachometer: } \\ & \text { Tool for measuring engine speed }\end{aligned}$




\subsubsection{Tool}

The tools used are dynotest, tachometer, burrete, fullset key, and stopwatch as shown in Table 4.

\subsection{Equations}

The calculation of engine performance is based on the results of testing the conditions performed at $4000 \mathrm{rpm}$ (rpm) up to the maximum rotation, with the throttle system as follows:

Torque ( $\mathrm{T})$, measured in test results.

Power $(\mathrm{P})$, measured on the test results

$$
\begin{array}{ll}
\mathrm{P} & =7,657 \mathrm{HP} \\
1 \mathrm{HP} & =0,7457 \mathrm{~kW} \\
\mathrm{P} & =5,709 \mathrm{~kW}
\end{array}
$$

Calculation of fuel consumption $\left(m_{f}\right)$ using a burette:

$$
m_{f}=\frac{b}{t} \cdot \frac{3600}{1000} \cdot \rho b b(\mathrm{~kg} / \mathrm{h})[7]
$$

Where, $\mathrm{b}=$ volume of the burette (cc); $\mathrm{t}=$ waktu (seconds); $\rho b b=$ fuel density (kg/liter).

Formula for calculating cylinder volume:

$$
V s=\frac{\pi}{4} \times D^{2} \times S
$$

Where, Vs = volume of the piston rod step $\left(\mathrm{cm}^{3}\right)$ or (cc); $\mathrm{D}=$ piston diameter $(\mathrm{cm}) ; \mathrm{S}=$ piston step length/stroke (cm).

The formula calculates the compression ratio

$$
r=\frac{V L+V c}{V c}=\frac{V L}{V s}+1
$$

Where, $r=$ compression ratio $(\mathrm{cc})$; VL $=$ volume of the piston rod step $\left(\mathrm{cm}^{3}\right)$ or $(\mathrm{cc})$; $\mathrm{Vc}=$ combustion chamber volume or residual volume (cc).

\subsection{Test Tool Scheme}

The test results are the results of testing the power, torque and fuel consumption of each test. Power and torque data are taken from the spontaneous throttle system and fuel consumption data is taken from engine speed (rpm). Retrieval of data each carried out as many as 3 testing cycles and then taken an average value. Test tool scheme can be seen in Figure 1.

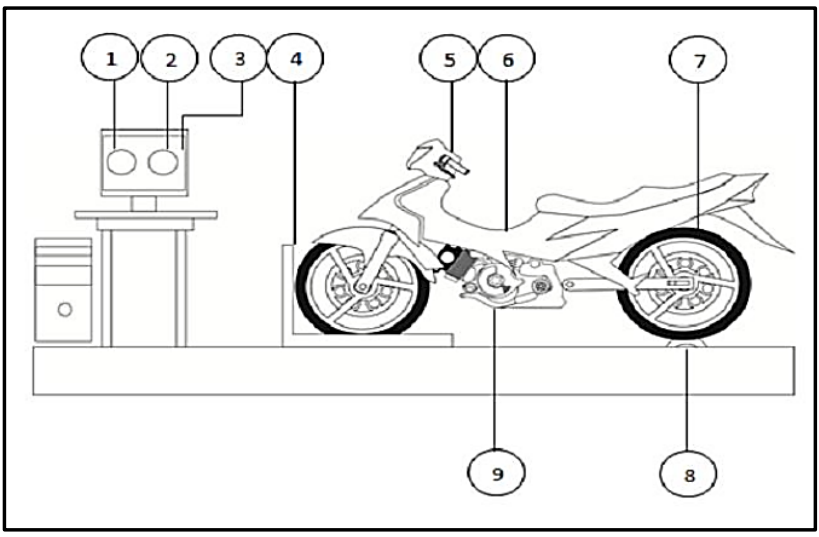

Figure 1. machine test tool scheme schema description:
1) Torquemeter
2) Tachometer
3) Computer
4) Motorcycle body brace
5) Fuel indicator
6) Carburettor
7) Exhaust Manifold
8) Dynamometer
9) Machine.

\section{Result and Discussion}

\subsection{Torque and Power on Standard Engine Conditions, Semi Racing (Bore up 150 cc Standard Cylinder Head) and Full Racing (Bore up 150 cc Racing Valve)}

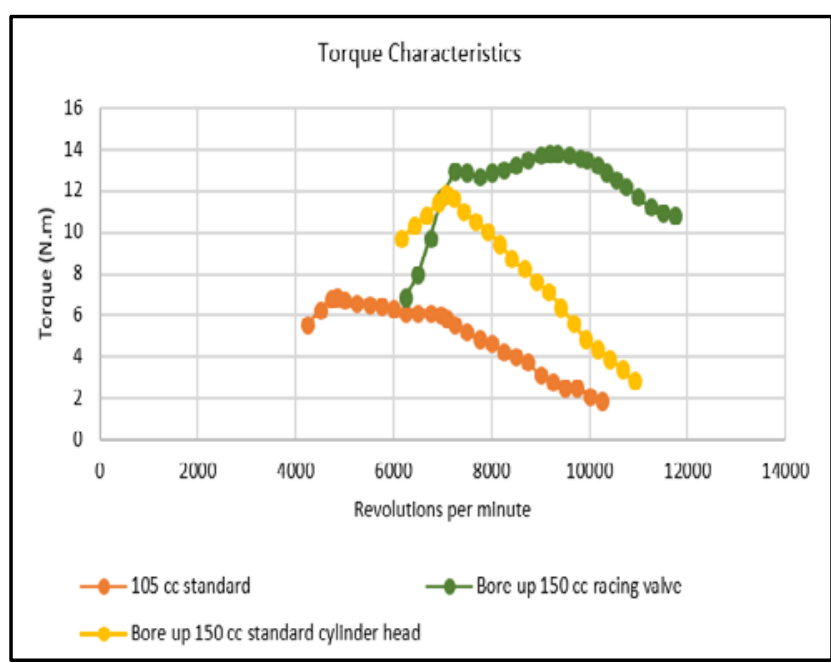

Figure 2. Torque characteristic

Seen in Figure 2 shows that the torque of the 150 cc standard cylinder head bore up and 150 cc racing valve bore up is higher than the $105 \mathrm{cc}$ standard due to the enlargement of the cylindrical volume and the replacement of other components such as racing carburetors, cylinder head racing, spark plug racing, CDI racing, racing coil, and racing exhaust so that the higher compression ratio will affect the pressure of the combustion results in the cylinder and enhance the work efficiency of the engine.

The torque obtained at the standard 150 cc cylinder head bore up is lower than the 150 cc torque racing valve bore up due to the use of standard cylinder heads and standard valves so that fuel is able to enter and meet the cylinder volume a little, and affect the cylinder volumetric efficiency. the higher the efficiency of the motor, the higher the ability of the motor to produce power

With increasing engine speed (rpm) to obtain an increase in maximum torque, the maximum torque will return to the minimum even though engine speed continues to increase. this is because the time available to carry out the combustion process at high speed is very short, so that the fuel in the fuel chamber does not burn completely. 


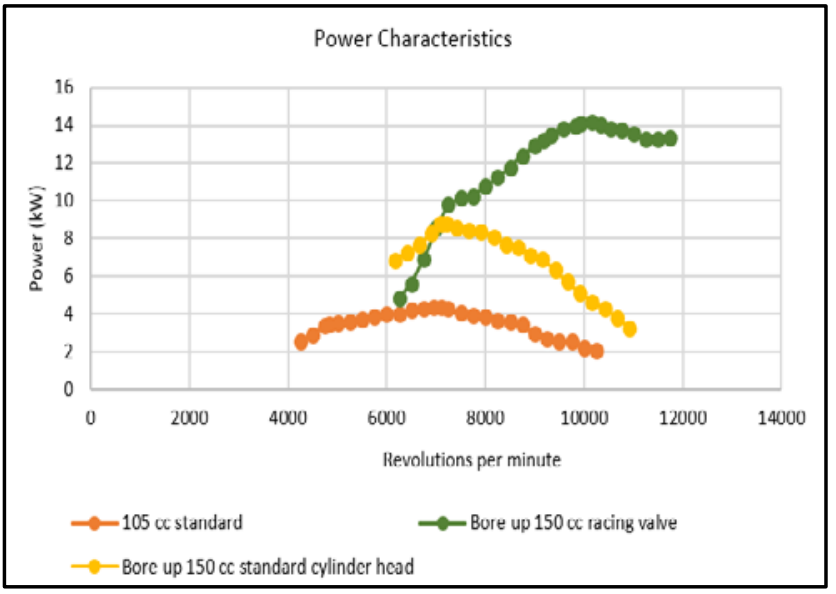

Figure 3. Power characteristic

Shown in Figure 3 shows that the power of the 150 cc standard cylinder head bore up and 150 cc racing valve bore up is higher than the 105 сc standard due to the enlargement of the cylinder volume and the replacement of other components. Maximum power of 150 cc standard cylinder head bore up is lower than 150 cc racing valve bore up due to the use of standard cylinder head and standard valve so that the fuel that is able to be sucked and meets the cylinder volume is a little, it affects the volumetric cylinder efficiency. The higher the engine efficiency, the higher the engine's ability to produce power.

The maximum power of a standard 150 cc cylinder head bore up is lower than the $150 \mathrm{cc}$ torque racing valve bore up due to the use of standard cylinder heads and standard valves so that fuel is able to enter and meet the cylinder volume a little, and affect the cylinder volumetric efficiency, the higher the efficiency of the motor, the higher the ability of the motor to produce power

With increasing engine speed (rpm) to obtain an increase in maximum power rotation, the maximum power will decrease again even though the engine speed continues to increase. at the end of each cycle of the combustion engine has decreased performance due to the higher engine rotation, the greater the friction generated so that the power obtained is used to withstand the friction force

\subsection{Fuel Consumption $\left(m_{f}\right)$ on Standard Engine Conditions, Semi Racing (150 cc Standard Bore up Head) and Full Racing (150 cc Bore up Racing Valve)}

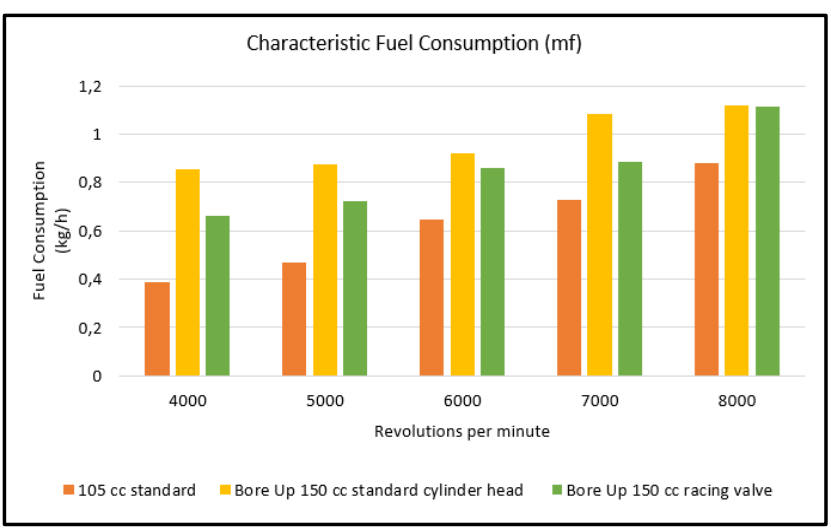

Figure 4. Fuel consumption
Seen in Figure 4. Fuel consumption $(m f)$ at 150 cc standard cylinder head bore up is higher than 150 cc racing valve bore up. Fuel consumption at 105 cc standard at least than 150 cc standard cylinder head bore up and 150 cc racing valve bore up. at 105 cc 4000 engine speed requires a fuel consumption of $0.388 \mathrm{~kg} /$ hour, at $150 \mathrm{cc}$ the standard cylinder head bore up requires a fuel consumption of $0.855 \mathrm{~kg} /$ hour, and at $150 \mathrm{cc}$ racing valve bore up requires a fuel consumption of $0.660 \mathrm{~kg} /$ hour

This is influenced by the use of standard head and standard valve. In the combustion chamber, the engine's volume capacity is getting wider, while the distance of the standard head to the cylinder block is too close so that the cylinder head gasket needs to be added. The addition was made to minimize the possibility of collisions between standard valves and piston racing. However, the impact of the addition of the gasket is the deviation of the opening and closing of the valve caused by fuel leakage due to the seal of the piston ring and valve which cannot be perfect

\subsubsection{Standard 105 Cc Engine Fuel Consumption over Time (Seconds)}

Standard 105 cc engine fuel consumption at each engine speed is shown in Table 5 and Figure 5.

Table 5. Fuel consumption over time (seconds)

\begin{tabular}{|c|c|c|}
\hline RPM & time (seconds) & $m_{f}$ \\
\hline 4000 & 69,33 & 0,388 \\
\hline 5000 & 57,17 & 0,47 \\
\hline 6000 & 41,54 & 0,647 \\
\hline 7000 & 37,06 & 0,729 \\
\hline 8000 & 30,6 & 0,879 \\
\hline
\end{tabular}

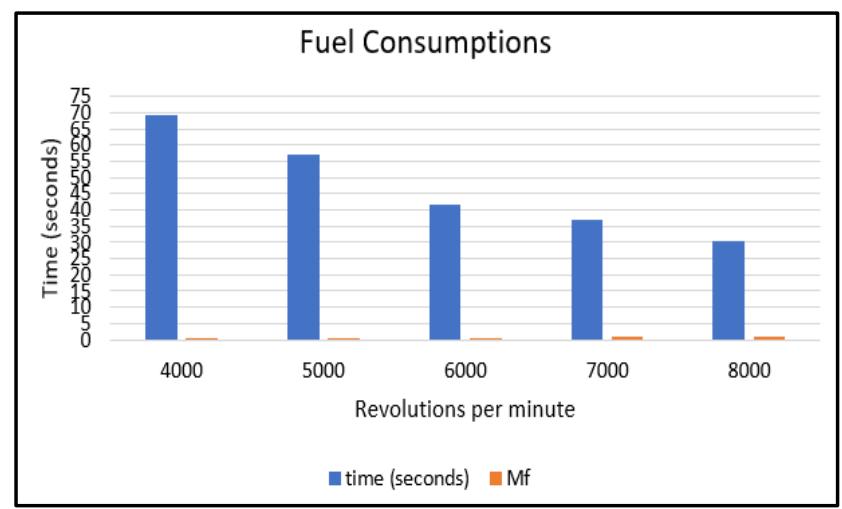

Figure 5. Standard 105 cc engine fuel consumption

\subsubsection{Bore up 150 cc (Standard Cylinder Head) Fuel Consumption over Time (Seconds)}

Bore up 150 cc (standard cylinder head) engine fuel consumption at each engine speed is shown in Table 6 and Figure 6.

Table 6. fuel consumption over time (seconds)

\begin{tabular}{|c|c|c|}
\hline RPM & time (seconds) & $m_{f}$ \\
\hline 4000 & 31,47 & 0,855 \\
\hline 5000 & 30,79 & 0,874 \\
\hline 6000 & 29,18 & 0,922 \\
\hline 7000 & 24,89 & 1,081 \\
\hline 8000 & 24,06 & 1,118 \\
\hline
\end{tabular}




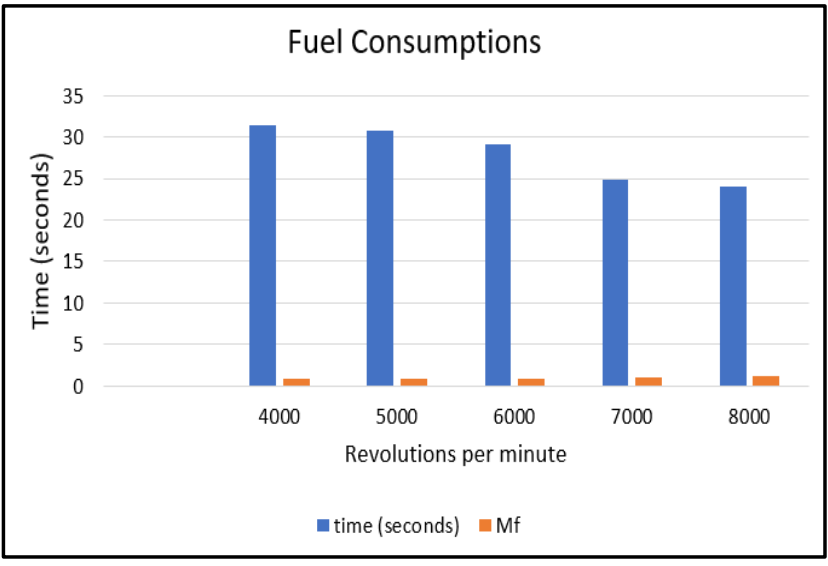

Figure 6. Bore up 150 cc (standard cylinder head) fuel consumption

\subsubsection{Bore up 150 cc (Racing Valve) Fuel} Consumption Over Time (Seconds)

Bore up 150 cc (racing valve) fuel consumption at each engine speed is shown in Table 7 and Figure 7.

Table 7. Fuel consumption over time (seconds)

\begin{tabular}{|c|c|c|}
\hline RPM & time (seconds) & $m_{f}$ \\
\hline 4000 & 40,78 & 0,66 \\
\hline 5000 & 37,3 & 0,721 \\
\hline 6000 & 31,22 & 0,861 \\
\hline 7000 & 30,45 & 0,883 \\
\hline 8000 & 24,1 & 1,116 \\
\hline
\end{tabular}

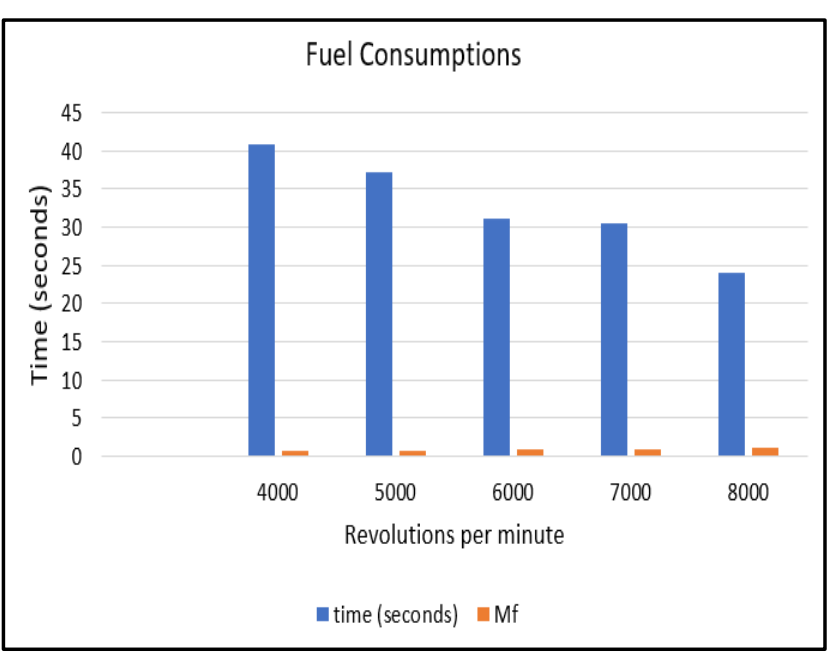

Figure 7. Bore up 150 cc (standard cylinder head) fuel consumption

\subsection{Torque (T), Power (P), and Fuel Consumption $\left(m_{f}\right)$ Results}

The percentage increase in torque, power and fuel consumption under conditions of 150 cc standard cylinder head bore up and $150 \mathrm{cc}$ racing valve bore up compared to the standard 105 cc conditions are shown in Table 8 and Figure 8.

In the condition of 150 cc standard cylinder head bore up increased torque of 4.82 , power by 4.23 , and fuel consumption by 0.24 , whereas in conditions of $150 \mathrm{cc}$ racing valve bore up experienced torque of 8.24 , power by 6.89 , and fuel consumption by 0.24 .

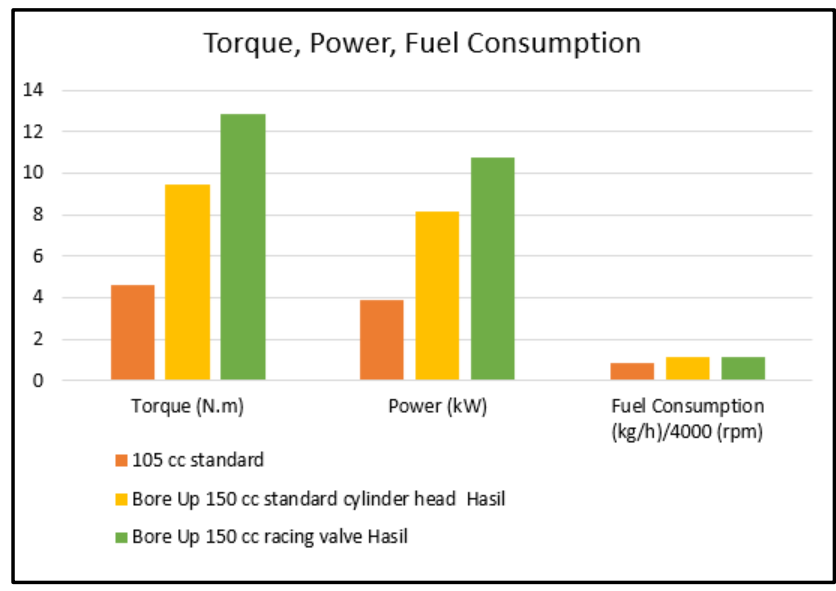

Figure 8. Torque, power, and fuel consumption result

Table 8. Torque, power, and fuel consumption result on percentage

\begin{tabular}{|c|c|c|c|c|}
\hline \multirow{2}{*}{ Parameter } & \multirow{2}{*}{105 cc standard } & \multicolumn{3}{|c|}{$\begin{array}{c}\text { Bore up } 150 \text { cc } \\
\text { (standard cylinder head) }\end{array}$} \\
\hline & & Result & Increase & $\begin{array}{c}\text { Percentage } \\
(\%)\end{array}$ \\
\hline Torque (N.m) & 4,63 & 9,45 & 4,82 & 104,10 \\
\hline Power $(\mathrm{kW})$ & 3,9 & 8,13 & 4,23 & 108,46 \\
\hline $\begin{array}{l}\text { Fuel consumption } \\
(\mathrm{kg} / \mathrm{h})\end{array}$ & 0,879 & 1,118 & 0,24 & 27,19 \\
\hline \multirow[b]{2}{*}{ Parameter } & \multirow{2}{*}{105 cc standard } & \multicolumn{3}{|c|}{ Bore up 150 cc (racing valve) } \\
\hline & & Result & Increase & $\begin{array}{c}\text { Percentage } \\
(\%)\end{array}$ \\
\hline Torque (N.m) & 4,63 & 12,87 & 8,24 & 177,97 \\
\hline Power $(\mathrm{kW})$ & 3,9 & 10,79 & 6,89 & 176,67 \\
\hline $\begin{array}{l}\text { Fuel consumption } \\
(\mathrm{kg} / \mathrm{h})\end{array}$ & 0,879 & & & \\
\hline
\end{tabular}

\section{Conclusion}

By reviewing research activities that include the overall data collection process, it can be concluded that:

1) In full racing conditions, torque and power are higher compared to standard and semi racing conditions

2) In semi-racing conditions, fuel consumption is higher compared to standard and full racing conditions

\section{Acknowledgements}

This research received no specific grant from any funding agency in the public, commercial, or not-forprofit sectors.

\section{References}

[1] Statistical Data Center, 2019, Development of the Number of Motorized Vehicles.

[2] MoT, 2018, Regulation of the Minister of Transportation of the Republic of Indonesia, pp 2-4.

[3] Lestari, DS., Darlius, IS., 2018, Upaya Meningkatkan Performa Mesin Yamaha Vega R Dengan Melakukan Bore Up Dan Stroke Up, Jurnal Pendidikan Teknik Mesin, Volume 5, Nomor 1, Mei 2018. 
[4] Majedi, F., Puspitasari, Indah., 2017, Optimasi Daya dan Torsi pada Motor 4 Tak dengan Modifikasi Crankshaft dan Porting pada Cylinder Head, Jurnal Teknologi Terpadu Vol. 5 No. 1 April 2017.

[5] Brinnen, M., Laggar, G., 2016, New Cutting Tool Concept For Cylinder Boring, Uppsala Universitet.
[6] Xu, ChangChun., Cho, HaengMuk., 2017, The Analysis of Influence of Throttle Body on Engine Intake System, International Journal of Engineering and Technology (IJET).

[7] Gupta, HN., 2013, Fundamental of Internal Combustion Engine, Delhi: PHI Learning Private. Ltd.

[8] Daryanto, 2011, Prinsip Dasar Mesin Otomotif, Bandung: Alfabeta.

(C) The Author(s) 2019. This article is an open access article distributed under the terms and conditions of the Creative Commons Attribution (CC BY) license (http://creativecommons.org/licenses/by/4.0/). 